\title{
ALERATIONS IN SCHOOL EXPERIENCE AND AFFECTIVE-BEHAVIORAL \\ SYMPTOMS IN CHILDREN AND ADOLESCENTS OF CALDAS - COLOMBIA
}

Felipe Agudelo-Hernández, Luisa Cardona-Porras, Fernando Arango, Adonilso Julio-De La

Rosa, Sonia De La Portilla-Maya, Marcela Guapacha-Montoya, Carlos Muñoz-Vinasco. UNIVERSIDAD DE MANIZALES - UNIVERSIDAD DE CALDAS

\section{Objective}

To determine the relationship between alterations in school experience in children and adolescents and affective and / or behavioral symptoms.

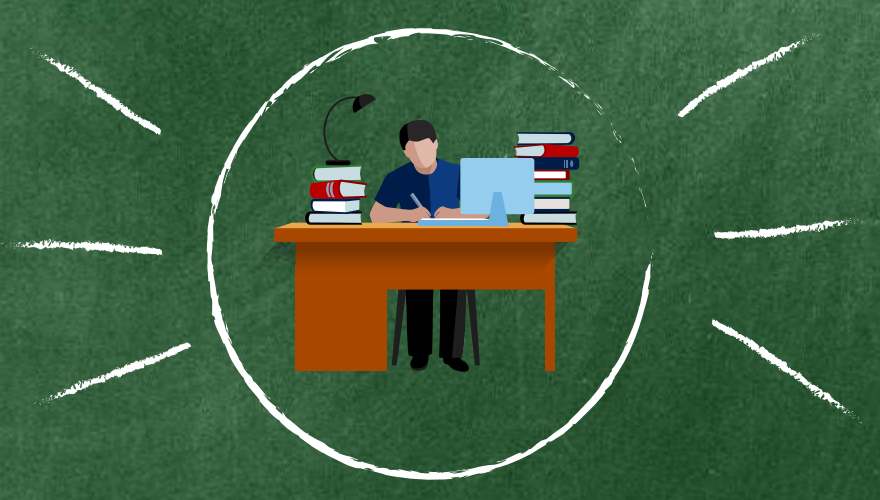

\section{Background}

Affective and behavioral alterations in children and adolescents tend to be related to difficulties in school adaptation, both social and in academic performance. This has been associated in the long term with suicidal behavior and early school drop-out. Identifying these alterations in educational institutions could help provide early management.

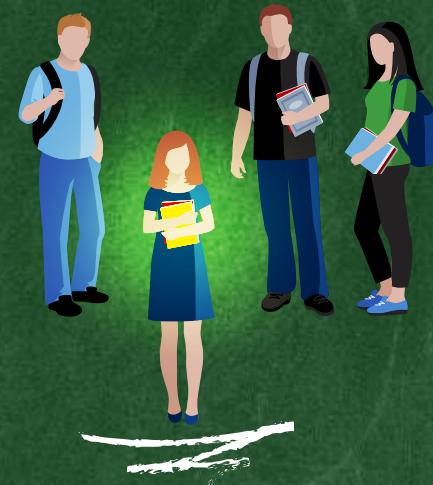

\section{Materials and methods:}

Cross-sectional, descriptive, correlation-based research conducted in 1535 children and adolescents from public schools in Manizales and Aranzazu (Caldas-Colombia), aged between 5 and 18 years old. The Child Behavior Checklist 4-18 (CBCL / 4-18) was applied to the main caregivers, seeking to determine children's abilities or competencies, especially in the school setting and problematic behaviors. The data was analyzed looking for correlation between both fields of information

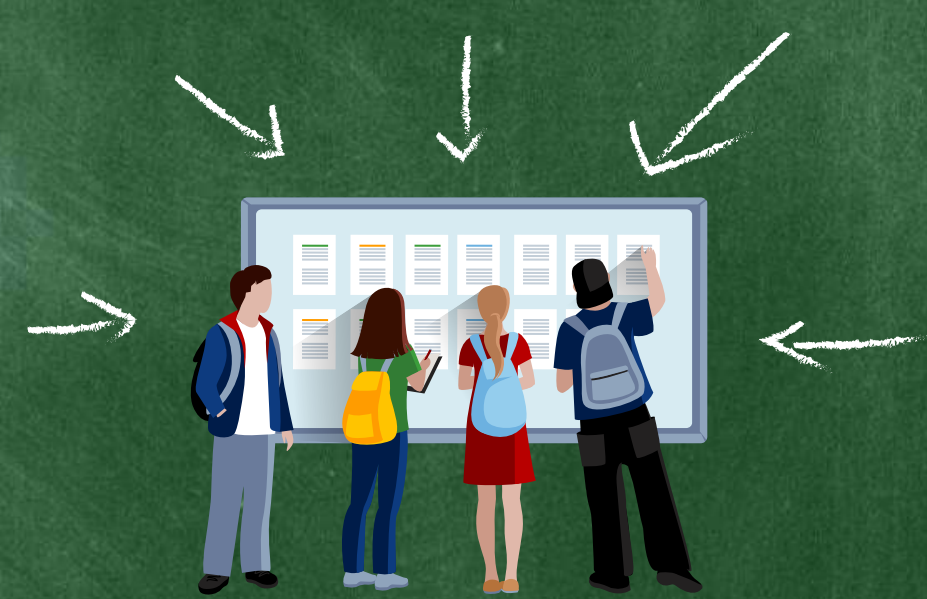

\section{Results}

$44.8 \%$ of children and adolescents presented affective-behavioral difficulties.
Of the total, $10.3 \%$ speak of suicide, finding a correlation between this variable and presenting risk symptoms in CBCL.
Children and adolescents who have higher means in CBCL, tend to be men, with health problems, do not play sports, have worse behavior than their peers, have repeated grades and have had problems at school, including lower performance in the classes.

\section{Conclusion}

Difficulties in school experience in children and adolescents are associated with behavioral and affective symptoms.

References:

DeFosset AR, Gase LN, liadi-Maghsoodi R, Kuo T. Youth Descriptions of Mental Health Needs and Experiences with School-based Services: Identifying Ways to Meet the Needs of Underserved Adolescents. J Health Care Poor Underserved. 2017;28(3): 1191-1207).

Leigh M, David V, Stan K. Mental health in schools: how teachers' have the power to make a difference. Sun Life Financial, Dalhousie University and IWK Health Centre. Teachers' attitude mental health articles. Available at:http://mhliteracyplc.commons.hwdsb.on.ca/files/2011/09/Teacher-AttitudesMental-Health-articles Accessed: 21 August 2013.

Hawker DS, Boulton W. Twenty years research on peer victimization and psychosocial maldaius ment: a meta-analyticreview of cross-sectional studies. J Child Psychol Psychiory. 2000 May: 41 (4):441-55.

Mandy L, McLennan D. Teacher perceived mental and learning problems of children referred to a school mental health service. J Can Acad Child Adolesc
Psychiatry 2010; 19:94-9. Oshodi OY, Aina OF, Adeyemi JD, Oduguwa TO Ogundipe $O A$. Perceived needs for school mental health among stakeholders in districts of South-west Nigeria. J Public Health Epidemiol 2013;5: 153-9.

Reinke WM, Stormont M, Herman KC, Puri R, Goel N. Supporting children's mental health in schools: teacher perceptions of needs, roles, and barriers Sch Psychol O 2011;26:1-13.

Copyright ๑ 2019 Author Names (Felipe Agudelo-Hernández, Luisa Cardona-Porras, Fernando Arango, Adonilso Julio-De La Rosa, Sonia De La Portilla- Maya, Marcela Guapacha-Montoya, Carlos Muñoz-Vinasco.)

Contact (afagudelo81703@umanizales.edu.co). 